\title{
Editorials
}

\section{Achieving a better knowledge on the causes and early course of psychoses: a profitable investment for the future?}

\author{
Editoriali \\ Ottenere una maggiore conoscenza sulle cause e sulle fasi iniziali \\ del decorso delle psicosi: un investimento fruttuoso per il futuro?
}

\author{
MIRELLA RUGGERI, Guest Editor \\ and MICHELE TANSELLA, Editor
}

Three challenges, among the many ones that psychiatric epidemiology must face in the future, have the potential to contribute greatly to the improvement of the mental health of the population: a) to favour mental health promotion and primary and secondary prevention; b) to increase the capability of mental health services to treat mental disorders at their onset in an innovative, efficacious and non stigmatising way; c) to understand the interplay between environmental and biological factors in determining individuals' vulnerability to mental illness and its outcome.

The treatment of psychoses is at the forefront of this agenda for action. This is not only because of the urgency to reduce the impact of such severe disorders on lives of the patients and their families, but also because of the need for a better understanding of the nature of psychosis. To achieve this, both the common ground shared by the different diagnostic entities into which the original concept of psychosis has been split in the existing classificatory systems (Maj, 1998) and the distinguishing characteristics of these syndromes - either they relate to the biological background, the pre-morbid status or the disability in the long term run (Dikeos et al., 2006) - need to be addressed.

The three Editorials published in this issue of EPS continue the exploration of the multifaceted aspects of psychosis proposed in some recent issues of the Journal (Cooper, 2005; Jablensky, 2005; Di Forti \& Murray, 2005; Keshavan et al., 2005; Bresnahan et al., 2005; McGrath \& Scott, 2006; Spauwen \& vanOs, 2006) and provide an important contribution to the above mentioned challenge.

In the first Editorial, Eoin Killakey, Alison Yung and Patrick McGorry (Killakey et al., 2007) from the Department of Psychiatry of the University of Melbourne, present the state of the art on early interventions in psy-
Tre sfide, fra le tante che l'epidemiologia psichiatrica dovrà affrontare in futuro, sono essenziali per il miglioramento della salute mentale della popolazione: a) la promozione della salute mentale e la prevenzione primaria e secondaria; b) aumentare la capacità dei servizi di salute mentale di trattare in maniera innovativa, efficace e non stigmatizzante i disturbi mentali al loro esordio; c) comprendere l'interazione fra fattori ambientali e genetici nel determinare la vulnerabilità di un individuo ai disturbi psichici e il loro esito.

Il trattamento delle psicosi è il terreno su cui questa sfida è stata affrontata più precocemente. Ciò è accaduto non solo per l'urgenza di ridurre l'impatto che tali disturbi hanno sulla vita dei pazienti e delle loro famiglie, ma anche per la necessità di ottenere una maggiore comprensione della natura stessa della psicosi. A questo fine, occorre tener conto sia dei fattori comuni alle diverse entità diagnostiche in cui il concetto originario di psicosi è stato frammentato nei sistemi diagnostici vigenti (Maj, 1998), che delle caratteristiche che contraddistinguono ciascuno di questi disturbi, facendo riferimento al background biologico, alle condizioni pre-morbose e alla disabilità che si rileva nel lungo periodo (Dikeos et al., 2006).

I tre Editoriali pubblicati in questo numero di EPS continuano l'analisi degli sfaccettati aspetti delle psicosi proposti in alcuni recenti numeri della Rivista (Cooper, 2005; Jablensky, 2005; Di Forti \& Murray, 2005; Keshavan et al., 2005; Bresnahan et al., 2005; McGrath \& Scott, 2006; Spauwen \& van Os, 2006) e forniscono un contributo importante nell'affrontare la sfida sopra citata.

Nel primo Editoriale, Eoin Killakey, Alison Yung e Patrick McGorry del Department of Psychiatry dell'Università di Melbourne (Killakey et al., 2007), pre- 
chosis, from their perspective as one of the leading groups in this field. The authors suggest that early interventions should be considered as part of the mainstream approach that has been proven to be effective in reducing the duration of untreated illness and, to some extent, to improve outcome. Even if contradictory findings are available in the literature on some effects of early intervention strategies (Olsen \& Rosenbaum, 2006) and further knowledge has still to be obtained regarding the cost benefits of this approach (Menezes et al., 2006), placing this issue at the very centre of the current debate on psychosis has already contributed to a new way of thinking about the prognosis of psychoses and to promote new efforts in implementing the development, or the refinement, of effective psychological and psychosocial interventions (Penn et al., 2005; Birchwood \& Trower, 2006; Garety et al., 2006; Kuipers \& Bebbington, 2006). The most promising approaches at present seem to be taking two complementary directions: secondary prevention focussed on early illness course - the so called "critical period" covering the first 5 years from onset; appropriate interventions for people at high risk, and those subjects in the pre-psychotic stage. However, there are some potential problems in these approaches: the former approach has the risk that people with brief good prognosis psychotic episodes are likely to receive unnecessary treatment. The latter approach might have a considerable negative impact on those individuals who are inaccurately labelled as being at imminent risk of psychosis and are treated accordingly (Warner, 2002). Both approaches will greatly contribute to an improvement in the prognosis of psychosis and are likely to become milestones in re-writing the story of the course of psychoses.

In the second Editorial, Paola Salvatore and Colleagues from the research group leaded by Ross Baldessarini (Salvatore et al., 2007) at the Harvard Medical School in Boston, using data from the McLean-Harvard First Episode Project, explore the specificity of the early course of bipolar disorder and confute some stereotypes about it having a more benign course than other psychoses. The findings they present highlight that, if $98 \%$ of subjects having experienced a first episode of mania or mixed state no longer fulfil the DSM-IV diagnostic criteria for this disorder after 24 months, only $72 \%$ are symptomatically well, and only $43 \%$ had returned to baseline functioning. This picture refutes the idea that bipolar disorder is a more benign mental illness; it also suggests that a recovery from symptoms should not be seen as the only goal for a successful treatment and that therapeutic strategies that guarantee the best possible recovery of functioning should be implemented and tested. Several methodological biases might have contributed to this confusion: the vast sentano lo stato dell'arte sugli interventi precoci nelle psicosi, così come esso appare secondo il punto di vista di uno dei gruppi leader in questo campo. Gli autori affermano che gli interventi precoci debbono essere considerati una componente fondamentale dell'approccio terapeutico alle psicosi; essi si sono dimostrati efficaci nel ridurre la durata del periodo di mancato trattamento (Duration of Untreated Psychosis) e, secondo alcune evidenze, nel migliorare l'esito. Anche se i dati presenti in letteratura sui risultati degli interventi precoci appaiono in una certa misura contraddittori (Olson \& Rosenbaum, 2007), e nonostante siano necessari ulteriori e più affidabili dati sul rapporto costi/benefici di tale approccio (Menezes et al., 2006), è indubbio che il solo porre questo tema al centro del dibattito attuale sulle psicosi abbia già avuto il grande merito di favorire un nuovo modo di pensare alla loro prognosi e di promuovere rinnovati sforzi mirati a sviluppare trattamenti psicologici e psicosociali o a perfezionare quelli esistenti (Penn et al., 2005; Birchwood \& Trower, 2006; Garety et al., 2006; Kuipers \& Bebbington, 2006). Riteniamo che, al momento, gli approcci più promettenti siano da considerarsi, da un lato, la prevenzione secondaria centrata sulle prime fasi successive all'esordio - il cosiddetto "periodo critico" che copre i primi 5 anni dall'esordio - e, dall'altro lato, l'attuazione di interventi precoci per le persone ad alto rischio e per i soggetti che manifestano già sintomi prodromici. Entrambi gli approcci possono avere alcuni aspetti problematici. Il primo approccio comporta il rischio che soggetti affetti da episodi psicotici brevi e con buona prognosi ricevano trattamenti non realmente necessari. Il secondo approccio potrebbe avere un impatto negativo su coloro che venissero erroneamente ritenuti a rischio di psicosi e trattati di conseguenza (Warner, 2002). Entrambi gli approcci contribuiranno di certo al miglioramento della prognosi delle psicosi e hanno buone probabilità di diventare pietre miliari nel riscrivere la storia del loro decorso.

Nel secondo Editoriale, Paola Salvatore e Colleghi del gruppo di ricerca diretto da Ross Baldessarini alla Harvard Medical School di Boston (Salvatore et al., 2007), utilizzando dati tratti dal McLean-Harvard First Episode Project, esplorano la specificità delle prime fasi del decorso del disturbo bipolare e mettono in discussione alcuni stereotipi secondo cui i disturbi bipolari avrebbero un decorso più benigno delle altre psicosi. I dati che essi presentano mettono in luce che, se il $98 \%$ dei soggetti che hanno sperimentato un primo episodio di mania o di stato misto 24 mesi dopo è destinato a non soddisfare più i criteri DSM-IV per tale disturbo, soltanto il $72 \%$ non presenta sintomi e soltanto il $43 \%$ è ritornato al funzionamento premorboso. Questi risultati suggeriscono 
majority of studies so far, and especially those conducted on bipolar disorders, have been conducted on research participants in the mid course of illness, with an overselection of participants with a poorer prognosis; subjects who differ according to diagnosis and illness duration have been mixed. Finally, the intrinsic characteristics of illness, that in several cases can be characterized at onset purely by depressive symptoms, have certainly hampered the acquisition of good quality data in this field.

It is nowadays widely recognized that the outcome of psychosis is the result of a series of interactions between biological, social and treatment specific interactions over the life course (Kendler \& Baker, 2007). This complexity has attracted the attention of several scientists in the last decade and constitutes a very promising position from which to test gene environment interactions (Caspi \& Moffitt, 2006). Studies of the early stages of bipolar disorders, as the one presented in the Editorial by Salvatore et al. (2007), will allow us to disentangle the intrinsic clinical and psychological characteristics, from the effects of the environment and biological susceptibility.

In the third Editorial, Craig Morgan and Paul Fearon from the Institute of Psychiatry in London (Morgan \& Fearon, 2007), provide an overview of those adverse social experiences that may be aetiologically relevant in schizophrenia and specifically explore data concerning ethnicity from the UK AESOP Study and other studies. Research comparing the incidence of schizophrenia and other psychoses in the migrant populations, compared with the host population promises to shed new light on the aetiology of these disorders. The high incidence of schizophrenia in migrant and ethnic minority groups is one of the most consistent findings in psychiatric epidemiology (Cooper, 2005). These findings constitute a sort of quasiexperimental situation to test the existence of gene-environment interactions (Read et al., 2006). Interestingly, the data obtained in the studies presented in this Editorial, appear to support the view that social adversity across life course contributes to the increased rates of psychosis in the African Caraibbean population. Long-term separation from, and loss of, a parent before the age of 16 , and longterm markers of adult social adversity and exclusion (e.g. unemployment, living alone, limited social networks) have been identified as specific vulnerability factors. Thus, social policies that take into account the potentially devastating effect of these factors, and interventions specifically devised to decrease social isolation may contribute greatly to an improvement in the mental health in these particular groups.

Another finding reported in this Editorial is the importance and relevance of comparative studies in clarifying che la remissione dei sintomi non debba essere vista come il solo obiettivo di un trattamento soddisfacente e che strategie terapeutiche che garantiscano il miglior recupero possibile del funzionamento debbano essere promosse e testate. Parecchi bias metodologici potrebbero aver contribuito alla confusione vigente in questo ambito: la maggioranza degli studi esistenti, e specialmente quelli promossi sul disturbo bipolare, è stata condotta in fasi intermedie del decorso della malattia, selezionando una maggiore proporzione di soggetti con una prognosi sfavorevole; inoltre, nei vari studi sono frequentemente stati mischiati soggetti con diagnosi diverse e diverse durate di malattia. Infine, le caratteristiche intrinseche della malattia, che all'esordio può essere caratterizzata solamente da sintomi depressivi, hanno certamente contribuito a frenare l'acquisizione di dati di buona qualità in quest'ambito.

Oggi come oggi è ampiamente riconosciuto che l'esito delle psicosi è il risultato di una serie di interazioni, che avvengono nel corso della vita, fra fattori biologici, sociali e inerenti gli specifici interventi messi in atto. Questa complessità è stata al centro dell'attenzione di numerosi scienziati nell'ultimo decennio e costituisce un terreno assai promettente su cui studiare le interazioni fra geni ed ambiente (Kendler \& Baker, 2007). Studi sugli stadi precoci dei disturbi psichici, come quelli presentati nell'Editoriale di Salvatore e Colleghi, saranno estremamente utili per distinguere le caratteristiche psicologiche e cliniche intrinseche dall'effetto dell'ambiente e dalla vulnerabilità biologica.

Nel terzo Editoriale, Craig Morgan e Paul Fearon dell'Institute of Psychiatry di Londra (Morgan \& Fearon, 2007), forniscono una rassegna delle esperienze sociali sfavorevoli che possono avere un ruolo eziologico nella schizofrenia ed esplorano in particolare i dati che riguardano l'etnicità tratti dallo Studio AESOP condotto nel Regno Unito. Le ricerche che confrontano l'incidenza di schizofrenia e altre psicosi negli emigrati e nelle minoranze etniche con le stime rilevate nei soggetti autoctoni sono destinate a gettare nuova luce sull'eziologia di questi disturbi. In effetti, l'elevata incidenza di schizofrenia negli emigranti e nelle minoranze etniche è uno dei risultati confermati in maniera più chiara in epidemiologia psichiatrica (Cooper, 2005) e questi dati configurano una interessante situazione quasi-sperimentale in cui testare l'esistenza di interazioni geni-ambiente (Read et al., 2005). È cosa assai rilevante che i dati prodotti dagli studi presentati in questo Editoriale supportino l'ipotesi che le difficoltà sociali sperimentate nel corso della vita contribuiscano grandemente all'aumentata incidenza di psicosi nella popolazione Afro-caraibica. La separazione di lunga 
important clinical questions: 'Schneiderian' first rank symptoms were less frequent in the forms of schizophrenia occurring in the black ethnic group compared to white participants, whereas those symptoms were found more commonly in participants belonging to the black ethnic group suffering from affective psychoses. These data hint at the possibility that there may be ethnic differences in the clinical profile of psychosis and highligth the possibility that some of those previously considered core symptoms of a specific type of psychosis (schizophrenia) might characterize other psychoses too (Dikeos et al., 2006).

In conclusion, the questions on the aetiology of psychoses and on the factors that might favour the best possible outcome, if not completely answered, seem to have received some important "partial" answers so far. The scientific knowledge that is currently being provided - and possibly further refined in the future - in the areas of research explored in the three Editorials presented in this issue of EPS, should become part of the body of knowledge in this field and contribute towards the expertise of administrators, service planners and clinicians. In doing so, great improvements can be achieved in dealing with the most complex social phenomena that characterize the third millennium by devising effective preventive strategies and therapeutic interventions for psychoses (Danese, 2006). The accomplishments fulfilled in this field might also have a beneficial effect on the conceptualization and treatment of several other mental disorders at onset.

We believe that promoting good quality research on mental disorders at their onset, embedded within the framework of routine clinical practice, and at the same time working to pursue a timely, high quality and evidence-based care, are not only fundamental duties for mental health services, but also a profitable investment for the future of psychiatry.

\section{REFERENCES}

Birchwood M. \& Trower P. (2006). The future of cognitive-behavioural therapy for psychosis: not a quasi-neuroleptic. British Journal of Psychiatry 188, 107-108.

Bresnahan M., Schaefer C.A., Brown A.S. \& Susser E.S. (2005). Prenata determinants of schizophrenia: What we have learned thus far? Epidemiologia e Psichiatria Sociale 14, 194-197.

Caspi A. \& Moffitt T.E. (2006).Gene-environment interactions in psychiatry: joining forces with neuroscience. Nature Reviews. Neuroscience 7(7), 583-590.

Cooper B. (2005). Schizophrenia, social class and immigrant status: the epidemiological evidence. Epidemiologia e Psichiatria Sociale 14 $137-144$.

Danese A. (2006). A public health genetic approach for schizophrenia. Epidemiologia e Psichiatria Sociale 15, 185-193. durata dai genitori e la loro perdita, prima dei 16 anni, unitamente ad eventi che siano determinati da difficoltà ed esclusione sociale nel corso della vita adulta (quali disoccupazione, vivere soli, avere una ristretta rete sociale) sono stati identificati come fattori specifici di vulnerabilità. Per questo motivo, politiche sociali che tengano in considerazione l'effetto potenzialmente devastante di questi fattori e la promozione di interventi che mirino in maniera specifica a diminuire l'isolamento sociale nelle suddette fasce di popolazione potrebbero favorire il miglioramento della salute mentale di questo gruppo di soggetti. Un altro risultato riportato in questo Editoriale sottolinea il grande impatto conoscitivo che studi comparativi come questo potrebbero avere nel chiarificare importanti quesiti clinici: i sintomi "schneideriani" di primo rango sono risultati essere meno frequenti nelle forme di schizofrenia rilevate nei soggetti di colore piuttosto che nei caucasici, mentre la sintomatologia delle psicosi affettive comprendeva più frequentemente tali sintomi nei soggetti di colore. Questi dati suggeriscono la possibilità che alcuni dei sintomi considerati patognomonici di uno specifico tipo di psicosi (la schizofrenia in questo caso) possano caratterizzare anche altri tipi di psicosi (Dikeos et al., 2006).

In conclusione, i quesiti sull'eziologia delle psicosi e sui fattori che possono contribuire ad ottenere il miglior esito possibile, se non una risposta completamente esauriente, paiono aver a tutt'oggi ottenuto qualche importante risposta "parziale". Le conoscenze scientifiche ottenute - che auspicabilmente saranno ulteriormente perfezionate in futuro - nelle aree di ricerca esplorate nei tre Editoriali presentati in questo numero di EPS, dovrebbero diventare parte del bagaglio culturale e di esperienza degli amministratori, dei Responsabili dei Servizi e dei clinici tutti. Riteniamo che, se questo si realizzerà, grandi conquiste potranno essere ottenute per far fronte ai fenomeni sociali complessi che caratterizzano il terzo millennio e nel mettere a punto strategie di prevenzione efficaci ed interventi terapeutici per le psicosi.

Le conquiste nell'ambito delle psicosi potrebbero avere un effetto benefico anche sulla concettualizzazione e il trattamento di vari altri disturbi psichici al loro esordio.

Siamo convinti che promuovere una ricerca di buona qualità sui disturbi psichici al loro esordio, che sia fortemente agganciata alla pratica clinica di routine, e al contempo aumentare la capacità di perseguire l'attuazione di trattamenti tempestivi, di elevata qualità e basati sulle evidenze, siano non solo doveri fondamentali per i servizi di salute mentale, ma anche un investimento fruttuoso per il futuro della psichiatria. 
Di Forti M. \& Murray R.M. (2005). Cannabis consumption and risk of developing schizophrenia. Epidemiologia e Psichiatria Sociale 14, 184-187.

Dikeos D.G., Wickham H., Mcdonald C., Walshe M., Sigmundsson T., Bramon E., Grech A., Toulopoulou T., Murray R. \& Sham P.C. (2006). Distribution of symptom dimensions across Kraepelinian divisions. British Journal of Psychiatry 189, 346-353.

Garety P.A., Craig T.J., Dunn G., Fornells-Ambroji M., Colbert S., Rahaman N., Reed J., Power P. (2006).Specialized care for early psychosis: symptoms, social functioning and patient satisfaction. British Journal of Psychiatry $188,37-45$.

Jablensky A. (2005). The long and winding road of schizophrenia research. Epidemiologia e Psichiatria Sociale 14, 179-183.

Kendler K.S. \& Baker J.H. (2007). Genetic influences on measures of the environment: a systematic review. Psychological Medicine 37(5), 615-626.

Keshavan M., Diwadkar V. \& Rosenberg D.R. (2005). Developmental biomarkers in schizophrenia and other psychiatric disorders: Common origins, different trajectories? Epidemiologia e Psichiatria Sociale 14, 188-193.

Killakey E., Yung A.R. \& McGorry P. (2007). Early psychosis: where we've been where we still have to go. Epidemiologia e Psichiatria Sociale 16, 102-108.

Kuipers E. \& Bebbington P. (2006). Cognitive behaviour therapy for psychosis. Epidemiologia e Psichiatria Sociale 15, 267-275.

Maj M. (1998). Critique of the DSM-IV operational diagnostic criteria fro schizophrenia. British Journal of Psychiatry 172, 458-460.
McGrath J. \& Scott J. (2006). Urban birth and risk of schizophrenia: a worrying example of epidemiology where the data are stronger than the hypotheses. Epidemiologia e Psichiatria Sociale 15, 243-246.

Menezes N.M., Arenovich T. \& Zipursky R.B. (2006). A systematic review of longitudinal outcome studies of first-episode psychosis. Psychological Medicine 36(10), 1349-1362.

Morgan C. \& Fearon P. (2007). Social experience end psychosis. Insights from studies of migrant and ethinic minority groups. Epidemiologia e Psichiatria Sociale 16, 118-123.

Olsen K.A. \& Rosenbaum B. (2006). Prospective investigations of the prodromal state of schizophrenia: review of studies. Acta Psychiatrica Scandinavica 113, 247-272.

Penn D.L., Waldheter M.A., Perkins D., Mueser K. \& Lieberman J.A. (2005). Psychosocial treatment for first-episode psychosis: a research update. American Journal of Psychiatry 162, 2220-2232.

Read J., van Os J., Morrison A.P. \& Ross C.A. (2005). Childhood trauma, psychosis and schizophrenia: a literature review with theoretical and clinical implications. Acta Psychiatrica Scandinavica 112, 330350.

Salvatore P., Tohen M., Kalsa H.M.K., Baethge C., Tondo L. \& Baldessarini R. (2007). Longitudinal research on bipolar disorders. Epidemiologia e Psichiatria Sociale 16, 109-117.

Spauwen J. \& Van Os J. (2006). The psychosis proneness: psychosis persistence model as an explanation for the association between urbanicity and psychosis. Epidemiologia e Psichiatria Sociale 15, 252-257.

Warner R. (2002). Early intervention in schizophrenia: a critique. Epidemiologia e Psichiatria Sociale 11, 248-255. 